\title{
Perbandingan Performa Kuantitatif Sapi Brahman Cross di Peternakan Rakyat dengan di Perusahaan Komersial pada Umur 18-24 Bulan
}

\author{
M. Dima Iqbal Hamdani ${ }^{*}$, Ali Husni ${ }^{1}$, M. Tino Fajar ${ }^{1}$, Sulastri $^{1}$ \\ ${ }^{1}$ Jurusan Peternakan, Fakultas Pertanian Universitas Lampung \\ J1. Prof. Dr. Soemantri Brodjonegoro No. 1, Gedong Meneng, Bandar Lampung, 35145 \\ *Email korespondensi: dima.iqbal@fp.unila.ac.id
}

(Diterima: 16-5-2018; disetujui 20-8-2018)

\begin{abstract}
ABSTRAK
Penelitian ini bertujuan untuk membandingkan performa kuantitatif sapi brahman cross pada umur 18-24 bulan di peternakan rakyat dan di perusahaan komersial pada bulan Agustus sampai Oktober. Pengamatan dilakukan terhadap 50 ekor sapi brahman cross di perusahaan komersial dan 50 ekor sapi brahman cross di peternakan rakyat dengan menggunakan metode survey dan pengambilan sampel menggunaan purposive sampling. Peubah yang diamati meliputi ukuran-ukuran tubuh yang meliputi bobot badan, lingkar dada, panjang badan dan tinggi pundak. Hasil penelitian menunjukan bahwa sapi brahman cross di perusahaan komersial memiliki performa kuantitatif yang lebih tinggi dibandingkan dengan sapi brahman cross di peternakan rakyat. Sapi brahman cross di peternakan rakyat memiliki ratarata bobot badan $(271,12 \pm 26,03 \mathrm{~cm})$, lingkar dada $(154,04 \pm 6,01 \mathrm{~cm})$, panjang badan $(107,42 \pm 3,42 \mathrm{~cm})$, dan tinggi pundak $(124 \pm 2,23 \mathrm{~cm})$, sedangkan sapii brahman cross di perusahaan komersial memiliki ratarata bobot badan $(383,92 \pm 35,05 \mathrm{~kg})$, lingkar dada $(175,9 \pm 4,27 \mathrm{~cm})$, panjang badan $(111,1 \pm 6,99 \mathrm{~cm})$, dan tinggi pundak $(128,4 \underline{4}, 84 \mathrm{~cm})$.
\end{abstract}

Kata kunci: sapi brahman cross, bobot badan, lingkar dada, panjang badan, tinggi pundak.

\section{ABSTRACT}

Research was conducted to determine the quantitative performance of brahmancross catlle 1824 month in traditional farmer and commercial companies. Research was conducted on 50 brahmancross catlle in traditional farmer and 50 brahman cross catlle in commercial companies, sample observation is determined by purposive sampling. Research uses a survey conducted from August to October 2016. The results showed a quantitative brahman cross catlle in convensional farmer trait average body weight $(271,12 \pm 26,05 \mathrm{~kg})$, chest circumference $(154,04 \pm 6,01 \mathrm{~cm})$, body length $(107,42 \pm 3,42 \mathrm{~cm})$, and shoulder height $(124 \pm 2,23 \mathrm{~cm})$, and the results showed a quantitative brahman cross catlle in commercial companies trait average body weight $(383,92 \pm 36,06 \mathrm{~kg})$, chest circumference $(175,9 \pm 4,27 \mathrm{~cm})$, body length $(111,1 \pm 6,99 \mathrm{~cm})$, and shoulder height $(128,4 \pm 4,84 \mathrm{~cm})$. The results showed that brahman cross cattlein commercial companies have higher quantitative performance than those at the traditional farmer.

Keywords: brahman cross cattle, body weight, chest circumference, body lenght, shoulder height.

\section{PENDAHULUAN}

Usaha peternakan sapi di Indonesia semakin berkembang. Hal tersebut ditandai dengan semakin banyaknya masyarakat maupun daerah yang mengusahakan penggemukan sapi. Usaha penggemukan sapi sudah menyebar ke beberapa daerah di luar Jawa, antara lain di Aceh, Lampung, Sulawesi, Bali, NTB dan NTT. Usaha penggemukan sapi dapat dilakukan secara perseorangan dengan skala usaha kecil maupun oleh suatu badan usaha dengan skala usaha yang besar. Selain itu, ada pula yang mengembangkan usahanya dalam bentuk kelompok ternak atau peternakan rakyat (Siregar, 2006). Manajemen pemeliharaan sapi di perusahaan pada umumnya sudah dilakukan secara modern, baik dari sisi manajemen pemberian pakan, manajemen perkandangan hingga manajemen kesehatan sapi. Hal tersebut 
berbeda dengan manajemen pemeliharaan peternakan rakyat yang pada umumnya masih dilakukan secara konvensional, sesuai dengan motivasi pemeliharaannya sebagai usaha sampingan sehingga manajemen pemeliharaan tidak dilakukan secara maksimal.

Salah satu jenis sapi yang banyak dikembangkan di Indonesia adalah sapi brahman cross (BX). Sapi brahmancross merupakan silangan sapi brahman dengan sapi Eropa (Firdausi et al., 2012). Tujuan dari persilangan ini utamanya adalah menciptakan bangsa sapi potong yang mempunyai produktivitas tinggi dan mempunyai daya tahan terhadap suhu tinggi, caplak, kutu, serta adaptif terhadap lingkungan tropis yang relatif kering.

Sapi brahman di Australia secara komersial jarang dikembangkan secara murni dan banyak disilangkan dengan sapi HerefordShorthorn. Sapi brahman cross mulai dikembangkan di stasiun CSIRO's Tropical Cattle Research Centre Rockhampton Australia, dengan materi dasar sapi Brahman, Hereford dan Shorthorn dengan proporsi darah berturut-turut $50 \% ; 25 \%$ dan $25 \%$, sehingga secara fisik bentuk fenotip dan keistimewaan sapi brahman cross cenderung lebih mirip sapi brahman amerika karena proporsi genetiknya lebih dominan (Turner, 1977).

Sapi brahman cross umumnya dilepas di padang rumput dan kawin secara alami dengan pejantan. Manajemen peternakan lepas (grazing) pada padang penggembalaan yang sangat luas, mempunyai kesempatan exercise yang tanpa batas, tanpa tali hidung, dalam kumpulan, dengan pengawinan alami menggunakan pejantan, serta dengan ketersediaan pakan hijauan maupun pakan penguat yang mencukupi secara kuantitatif maupun kualitatif (Firdausi et al., 2012).

Pertumbuhan sapi sangat berkaitan dengan umur. Pada umur 18-24 bulan sapi mencapai pertumbuhan yang baik, hal ini dikarenakan proses pertubuhan sudah melewati dewasa kelamin sehingga pertumbuhannya sangat optimal.

Manajemen pemeliharaan sapi brahmancross di peternakan rakyat berbeda dengan di perusahaan sehingga diduga terdapat perbedaan performa kuantitatif sapi brahman cross yang dipelihara di peternakan rakyat dengan di perusahaan sapi komersial.

Berdasarkan uraian tersebut maka perlu dilakukan penelitian tentang perbedaan performa sapi brahmancross di peternakan rakyat dengan sapi brahman cross di perusahan komersial pada umur 18-24 bulan.

\section{MATERI DAN METODE}

Materi penelitian terdiri dari 100 ekor sapi brahman cross jantan berumur antara 18-24 bulan (poel 1). Sapi brahman cross tersebut 50 ekor terdapat di peternakan rakyat Desa Karang Endah dan 50 ekor yang terdapat di Perusahaan Indo Prima Beef. Alat yang digunakan dalam penelitian ini adalah timbangan merk Sonic A12E dengan ketelitian $0,1 \mathrm{~kg}$ dan kapasitas 5 ton, timbangan merk Tru-Test dengan ketelitian $0,1 \mathrm{~kg}$ dan kapasitas 5 ton, pita ukur merk Rondo dengan ketelitian $0,1 \mathrm{~cm}$ kapasitas $300 \mathrm{~cm}$, alat tulis, dan kamera.

Penelitian dilakukan dengan metode survei, pengambilan sampel didasarkan pada purposive sampling. Data yang diambil adalah data primer dengan melakukan penimbangan dan pengukuran terhadap sapi dan wawancara langsungdengan peternak menggunakan kuisioner.

Penelitian dilakukan dengan prosedur sebagai berikut: 1) Melakukan prasurvei di lokasi peternak; 2) menentukan sampel sapi brahman cross jantan yang akan diamati; 3) menentukan umur sapi yang dijadikan sampel yaitu 18-24 bulan (poel1); 4) mengoleksi data dengan cara menimbang, mengukur dan mencatat data dari sampel sapi brahman cross jantan; 5) melakukan analisis data. Peubah yang diamati adalah bobot badan, panjang badan, lebar dada, dan tinggi punuk. Data performa kuantitatif meliputi bobot badan, panjang badan, lebar dada, dan tinggi pundak ditampilkan dalam bentuk tabel dan diuji dengan menggunakan uji t.

\section{HASIL PENELITIAN}

Performa kuantitatif seekor sapi dapat diketahui melalui pengukuran ukuran tubuh dan penimbangan bobot badannya. Ukuran tubuh yang dapat digunakan untuk mengetahui performa kuantitatif sapi antara lain panjang badan, tinggi pundak, dan lingkar dada. Bobot dan ukuran-ukuran tubuh sapi yang dibandingkan pada penelitian ini yaitu bobot dan ukuran-ukuran tubuh antara sapi brahmancross di peternakan rakyat dengan di perusahaan komersial.

Panjang badan, tinggi pundak, lingkar dada, dan bobot badan sapi brahman cross di peternakan rakyat dengan di perusahaan komersial dapat dilihat dalam Tabel 1. 
Tabel 1. Perbandingan performa kuantitatif sapi Brahman cross di peternakanrakyat dan perusahaan komersial pada umur 18-24 bulan

\begin{tabular}{lcc}
\hline \multirow{2}{*}{ Peubah } & $\begin{array}{c}\text { Peternakan } \\
\text { Rakyat }\end{array}$ & $\begin{array}{c}\text { Perusahaan } \\
\text { Komersial }\end{array}$ \\
\cline { 2 - 3 } & Rata-rata & Rata-rata \\
\hline Panjang Badan $(\mathrm{cm})$ & $107,42 \pm 3,42^{\mathrm{a}}$ & $111,1 \pm 6,99^{\mathrm{b}}$ \\
Tinggi Pundak $(\mathrm{cm})$ & $124 \pm 2,23^{\mathrm{a}}$ & $128,4 \pm 4,84^{\mathrm{b}}$ \\
Lingkar Dada $(\mathrm{cm})$ & $154,04 \pm 6,01^{\mathrm{a}}$ & $175,9 \pm 4,27^{\mathrm{b}}$ \\
Bobot Badan $(\mathrm{kg})$ & $271,12 \pm 26,03^{\mathrm{a}}$ & $383,92 \pm 36,06^{\mathrm{b}}$ \\
\hline
\end{tabular}

Superskrip ${ }^{\mathrm{ab}}$ huruf yang berbeda pada baris yang sama menunjukkan perbedaan yang nyata $(\mathrm{P}<0.01)$

\section{Bobot Badan}

Rata-rata bobot badan sapi brahman cross di peternakan rakyat yaitu $271,12 \pm 26,03 \mathrm{~kg}$ sedangkan rata-rata bobot badan Sapi Brahman Cross di perusahaan komersial yaitu $383,92 \pm 35,05$ kg. Hasil uji-t menunjukkan bahwa rata-rata bobot badan sapi brahman cross pada peternakan rakyat dengan perusaahan komersial tersebut berbeda sangat nyata $(\mathrm{P}<0,01)$.

Rata-rata bobot badan sapi brahmancross berbeda nyata antara peternakan rakyat dengan perusahaan komersial disebabkan oleh perbedaan dalam manajemen pemeliharaan serta perbedaan dalam pemberian bahan pakan. Perusahaan komersial memberikan pakan sebesar $30 \mathrm{~kg}$ per hari dengan rincian $70 \%$ konsentrat dan $30 \%$ hijauan. Sedangkan pemberian pakan di peternakan rakyat hanya sebesar $18 \mathrm{~kg}$ perhari dengan rincian $80 \%$ konsentrat dan $20 \%$ hijauan. Hal ini sesuai dengan pendapat Roviki et al. (2014) faktor yang mempengaruhi produksi sapi adalah kecukupan nutrisinya, bila ternak mengalami kekurangan vitamin dan mineral maka akan berpengaruh pada proses metabolisme yang mengakibatkan terhambatnya produktivitas maupun pertumbuhannya.

Pakan adalah semua bahan makanan yang dapat diberikan kepada ternak dan tidak mengganggu kesehatan ternak. Kebutuhan ternak terhadap jumlah pakan tiap harinya tergantung dari jenis atau spesies, umur dan fase pertumbuhan ternak (dewasa, bunting dan menyusui). Penyediaan pakan harus diupayakan secara terus-menerus dan sesuai dengan standar gizi ternak tersebut. Pemberian pakan yang tidak sesuai dengan kebutuhan gizi ternak dapat menyebabkan defisiensi zat makanan sehingga mudah terserang penyakit (Winugroho, 2002).

Pada penelitian ini rata-rata protein pada bahan pakan yang diberikan untuk ternak di peternakan rakyat sebesar $12,71 \%$, sedangkan rata-rata protein pada bahan pakan yang diberikan untuk ternak di perusahaaan komersial sebesar $14,55 \%$. Perbedaan kadar protein ratarata bahan pakan pada peternakan rakyat dengan perusahaan komersial akan berpengaruh terhadap bobot badan ternak.

Protein sangat penting bagi tubuh baik itu pada manusia ataupun hewan. Apabila dalam bahan pakan protein tidak memenuhi kebutuhan hidup ternak maka tubuh tidak akan membentuk jaringan-jaringan yang harus digantikan, akibatnya pertumbuhan akan terganggu. Sapi yang baru lahir membutuhkan protein untuk pertumbuhan sedangkan sapi dewasa protein berfungsi sebagai pengganti jaringan yang telah rusak dan untuk produksi hal ini terjadi pada sapi brahman cross hasil penggemukan (Priyanto dan Hafid, 2006).

Manajemen pemeliharaan sapi juga akan sangat berpengaruh terhadap bobot badan ternak. Manajemen pemeliharaan sapi pada peternakan rakyat pada umumnya masih secara tradisional. Hal ini sesuai dengan pendapat Yusdja dan Ilham (2004) sistem pemeliharaan secara ekstensif dilakukan oleh banyak peternak dengan skala usaha rumah tangga dan kepemilikan ternak rendah. Teknologi yang diterapkan masih sederhana dan berbasis azas organisasi kekeluargaan.

Hasil penelitian menunjukan bobot badan rata-rata di peternakan rakyat $(271,12 \pm 26,03) \mathrm{kg}$ lebih rendah dibandingkan dengan penelitian Firdausi et al. (2012) dengan bobot $350 \mathrm{~kg}$, hal ini dikarenakan pakan yang diberikan oleh peternakan sapi rakyat belum mencukupi kebutuhan nutrisi sapi sedangkan bobot badan sapi di perusahaan komersial lebih tinggi $(383,92 \pm 35,05) \quad \mathrm{kg}$ dibandingkan dengan penelitian Firdausi et al. (2012) dikarenakan pakan yang diberikan oleh perusahaan komersial sudah mencukupi kebutuhan nutrisi sapi.

\section{Lingkar Dada}

Hasil penelitian menunjukan lingkar dada sapi brahman cross di peternakan rakyat $(154,04 \pm 6,01 \mathrm{~cm})$ lebih rendah dibandingkan dengansapi brahman cross di perusahaan komersial $(175,9 \pm 4,27 \quad \mathrm{~cm})$. Hasil uji-t menunjukkan bahwa lingkar dada sapi brahman cross di peternakan rakyat dengan di perusahaan komersial tersebut berbeda sangat nyata $(\mathrm{P}<$ $0,01)$.

Lingkar dada merupakan parameter penduga bobot badan terbaik pada semua tingkatan umur. Pertambahan bobot badan 
akandiikuti dengan pertambahan lingkar dada (Basbeth et al., 2015). Menurut Niam et al. (2012) lingkar dada mempunyai hubungan yang paling erat dengan bobot badan, hubungan antara bobot badan dengan lingkar dada lebih bertahan sampai umur yang lebih tua dibandingkan keeratan hubungan bobot badan dengan ukuranukuran tubuh lainnya.

Perbedaan lingkar dada antara perusahaan komersial dengan peternakan rakyat disebabkan oleh faktor manajemen pemeliharaan. Kebersihan kandang pada peternakan komersial selalu terjaga dengan jadwal sanitasi yang teratur, sedangkan pada peternakan rakyat jadwal sanitasi belum teratur dengan baik. Pada perusahaan komersial kandang dibersihkan dua hari sekali, sedangkan pada peternakan rakyat kandang dibersihkan tiga hari sekali karena pemilik kandang memiliki pekerjaan pokok yang lain.

Kebersihan kandang akan berpengaruh terhadap kondisi sapi, saat kandang kotor sapi akan mudah terserang penyakit dan akan menurunkan nafsu makan sapi sehingga pertumbuhan sapi tidak akan maksimal. Pertumbuhan sapi yang tidak maksimal akan terlihat dari lingkar dada sapi yang kecil.

Hasil penelitian menunjukan bahwa lingkar dada sapi di peternakan rakyat $(154,04 \pm 6,01 \mathrm{~cm})$ lebih rendah dibandingkan dengan Standar Nasional Indonesia (SNI) sapi brahman cross dengan lingkar dada $159 \mathrm{~cm}$, hal ini dikarenakan kebersihan kandang di peternakan sapi rakyat belum terjaga dengan baik sehingga sapi akan mudah terserang penyakit, sapi mudah stres, dan nafsu makan sapi juga akan menurun. Lingkar dada sapi di perusahaan komersial lebih tinggi $(175,9+4,27 \mathrm{~cm})$ dibandingkan dengan SNI $168 \mathrm{~cm}$, hal ini dikarenakan kebersihan kandang sapi di perusahaan komersial sudah terjaga dengan baik.

\section{Panjang Badan}

Hasil penelitian menunjukan panjang badan sapi brahman cross di peternakan rakyat $(107,42 \pm 3,42 \mathrm{~cm})$ lebih baik dibandingkan denganpanjang badan sapi brahman cross di perusahaan komersial $(111,1+6,99 \mathrm{~cm})$. Hasil uji-t panjang badan sapi brahman cross di peternakan rakyat dengan sapi brahman cross di perusahaan komersial menunjukkan hasil berbeda sangat nyata $(\mathrm{P}<0,01)$.
Rata-rata panjang badan sapi brahman cross di peternakan rakyat dengan sapi brahman cross perusahaan komersial menunjukan hasil berbeda sangat nyata karena adanya perbedaan kandungan mineral dalam bahan pakan yang diberikan ke sapi. Perusahaan komersial memberikan mineral sebesar 100-125gram per hari, sedangkan di peternakan rakyat sapi tidak diberikan mineral. Perbedaan pemberian mineral tersebut berpengaruh terhadap sapi yang dipelihara di perusahaan komersial dengan peternakan rakyat.

Kalsium (Ca) merupakan elemen mineral yang paling banyak dibutuhkan oleh tubuh ternak. Kalsium memiliki peranan penting sebagai penyusun tulang dan gigi. Selain itu kalsium berperan sebagai penyusun sel dan jaringan (McDonald, 1981). Fungsi kalsium yang tidak kalah pentingnya adalah sebagai penyalur rangsangan-rangsangan syaraf dari satu sel ke sel lain. Jika ransum ternak pada masa pertumbuhan kekurangan kalsium maka pembentukan tulang menjadi kurang sempurna.

Panjang badan juga mempunyai hubungan dengan bobot tubuh. Menurut Niam et al (2012) panjang badan menunjukkan adanya pertumbuhan tulang belakang yang meliputi tulang punggung dan tulang pinggang. Arah pertumbuhan ternak diawali dengan pertumbuhan meninggi kemudian memanjang dan kemudian melingkar pada dada.

Hasil penelitian menunjukan bahwa panjang badan sapi di peternakan rakyat $(107,42 \pm 3,42 \mathrm{~cm})$ lebih rendah dibandingkan dengan SNI sapi brahman cross $(132 \mathrm{~cm})$, hal ini disebabkan karena sapi brahman cross yang ada di peternakan rakyat tidak diberikan mineral sehingga akan berpengaruh terhadap panjang badan sapi. Panjang badan di perusahaan komersial juga lebih rendah $(111,1 \pm 6,99 \mathrm{~cm})$ dibandingkan dengan SNI sapi brahman cross $(132 \mathrm{~cm})$, hal ini disebabkan karena mineral yang diberikan untuk sapi belum mencukupi kebutuhan mineral sapi.

\section{Tinggi Pundak}

Hasil penelitian menunjukan tinggi pundak sapi brahman cross di peternakan rakyat $(124 \pm 2,23 \mathrm{~cm})$ lebih rendah dibandingkan tinggi pundak sapi brahman cross di perusahaan komersial $(128,4+4,84 \quad \mathrm{~cm})$. Hasil uji-t menunjukkan bahwa rata-rata tinggi pundak sapi brahman cross di peternakan rakyat dengan sapi brahman cross di perusahaan komersial berbeda sangat nyata $(\mathrm{P}<0,01)$. 
Tinggi pundak merupakan salah satu ukuran tubuh yang dapat digunakan sebagai data pendukung dalam penentuan performan ternak. Tinggi pundak dapat diukur dengan cara diukur lurus dengan tongkat ukur dari atas tanah tempat sapi berdiri sampai dengan titik tertinggi pada gumba, pada tulang rusuk ketiga dan keempat. Hubungan antara tinggi pundak dengan bobot akan semakin erat seiring dengan bertambahnya waktu (Niam et al., 2012).

Tinggi pundak ialah jarak tegak lurus dari titik tertinggi pundak sampai ke tanah atau lantai diukur menggunakan tongkat ukur. Ukuran-ukuran tubuh seperti lingkar dada, panjang badan dan tinggi pundak dapat memberikan petunjuk bobot badan ternak dengan ketelitian yang cukup baik. Korelasi antara lingkar dada, panjang badan, dan tinggi pundak dengan bobot hidup sangat tinggi dibandingkan dengan ukuran tubuh lainnya (Suryadi, 2003).

Perbedaan tinggi pundak antara perusahaan komersial dengan peternakan rakyat disebabkan karena mutu genetik sapi brahman cross yang terdapat di perusahaan komersial lebih baik dibandingkan sapi brahman cross yang ada di peternakan rakyat. Sapi brahmancross di perusahaan komersial berasal dari Australia yang memiliki mutu genetik yang baik, sedangkan sapi brahman cross di peternakan rakyat berasal dari perusahaan Great Giant Live Stock (GGLC). Sapi brahman cross yang ada di peternakan rakyat genetiknya bukan murni sapi brahman cross, namun sudah campuran dari berbagai jenis sapi sehingga pertumbuhan tinggi pundak sapi brahman cross di peternakan rakyat tidak maksimal.

Perbedaan genetik antara sapi Brahman cross yang ada di peternakan rakyat dengan Ssapi brahman cross yang ada di perusahaan komersial juga berpengaruh terhadap ukuranukuran tubuh. Sapi brahman cross yang ada di perusahaan komersial memiliki ukuran-ukuran tubuh yang maksimal dibandingkan dengan ukuran-ukuran tubuh sapi brahman cross yang ada di peternakan rakyat.

Hasil penelitian menunjukan bahwa tinggi pundak di peternakan rakyat $(124 \pm 2,23$ $\mathrm{cm}$ ) hampir sama dengan SNI sapi brahman cross dengan tinggi pundak $124 \mathrm{~cm}$ dan tinggi pundak di perusahaan komersial lebih tinggi $(128,4 \pm 4,84$ $\mathrm{cm}$ ) dibandingkan dengan SNI, hal ini disebabkan karena sapi brahman cross yang ada di perusahaan komersial memiliki mutu genetik yang baik.

\section{KESIMPULAN}

Rata-rata bobot badan, lingkar dada, panjang badan, dan tinggi pundak pada sapi brahmancross di perusahaan komersial lebih tinggi daripada di peternakan rakyat.

\section{DAFTAR PUSTAKA}

Badan Pusat Statistik, 2016. Lampung Tengah Dalam Angka. BPS Kabupaten Lampung Tengah.

Basbeth, A.H., W.S. Dilaga, \& A. Purnomoadi. 2015. Hubungan antara ukuran-ukuran tubuh terhadap bobot badan kambing jawarandu jantan umur muda di Kabupaten Kendal. Animal Agriculture Journal 4(1):35-40.

Firdausi, A., T. Susilowati, M. Nasich, \&Kuswati. 2012. Pertambahan bobot badan harian sapi brahman cross pada bobot badan dan frame size yang berbeda. Jurnal Ternak Tropika 13(1):4862.

McDonald, P. 1981. The Biochemistry of Silage. John Wiley and Sons Ltd. London.

Niam, H.U.M., A. Purnomoadi, \& S. Dartosukano. 2012. Hubungan antara ukuran-ukuran tubuh dengan bobot badan sapi bali betina pada berbagai kelompok umur. Animal Agriculture Journal 1 (1):541-556.

Priyanto, R dan H. Hafid. 2006. Pertumbuhan dan dan distribusi potongan komersial karkas sapi australian commercial cross dan brahman cross hasil penggemukan. Media peternakan 29(2):63-69

Roviki R., Kuswati., H. Nugroho, \& T. Susilowati. 2014. Produksi karkas sapi brahman cross steer pada frame size yang berbeda. Jurnal Ternak Tropika 13(1): $1-8$.

Siregar, 2006. Perkandangan Sapi Potong. Gramedia. Jakarta.

Standar Nasional Indonesia. 2011. SNI 7651.1:2011. Bibit Sapi Potong Bagian 1. Badan Standarisasi Nasional. Jakarta.

Suryadi, U. 2003. Karateristik karkas dan daging sapi brahman cross hasil penggemukan pada berbagai bobot potong. Buletin Peternakan 27(2):46-54. 
Turner HG. 1977. The tropical adaptation of beef cattle. An Australian study. In: animal breeding: Selected articles from the Word Anim. Rev. FAO Animal Production and Health Paper 1:92-97.

Winugroho, M. 2002. Strategi pemberian pakan tambahan untuk memperbaiki efisiensi reproduksi induk sapi. Jurnal Penelitian dan Pengembangan Pertanian 21(1):1923.

Yusdja, Y. \& N. Ilham.2004. Tinjauan kebijakan pengembangan agribisnis sapi potong. Jurnal Analisis Kebijakan Pertanian 2(2): 167-173. 